Journal of Marine Science and Technology; Vol. 15, No. 1; 2015: 35-44

DOI: $10.15625 / 1859-3097 / 15 / 1 / 4405$

http://www.vjs.ac.vn/index.php/jmst

\title{
SOME NEW RECORDS OF MARINE ALGAE FROM VIETNAM
}

\author{
Le Nhu Hau*, Bui Minh Ly, Tran Van Huynh, Vo Thanh Trung \\ Nha Trang Institute of Technology Research and Application-VAST \\ *E-mail: lenhuhau2003@yahoo.com
}

Received: 22-6-2014

\begin{abstract}
In May 2013, a scientific expedition was organized by the Vietnam Academy of Science and Technology and the Far Eastern Branch of the Russian Academy of Sciences (FEBRAS) in the frame of the VAST-FEBRAS International collaboration program. The expedition went along the coast of Vietnam from Quang Ninh to Kien Giang. The objective was to collect natural resources for investigation of the biological and biochemical diversity of the territorial waters of the Socialist Republic of Vietnam. Among the collected algae, six taxa are new records for the Vietnam algal flora. They are the red algae Titanophora pikeana (Dickie) Feldmann from Cu Lao Xanh Island, Laurencia natalensis Kylin from Tho Chu Island, and Coelothrix irregularis (Harvey) Børgesen from Con Dao Island, and the green algae Caulerpa oligophylla Montagne, Caulerpa andamanensis (Taylor, W. R., 1975) Draisma, Prudhomme et Sauvage from Phu Quy Island and Caulerpa falcifolia Harvey \& Bailey from Ly Son Island. The seaweed flora of Vietnam now counts 833 marine algal taxa, including 415 Rhodophyta, 147 Phaeophyceae, 183 Chlorophyta and 88 Cyanobacteria.
\end{abstract}

Keywords: Caulerpa, Coelothrix, Laurencia, marine algae, Titanophora, new records.

\section{INTRODUCTION}

The first major checklist of the marine algae of Vietnam was published by Nguyen et al., (2013) [1] recording 827 specific and infraspecific taxa. Among these, the Rhodophyta show the highest taxon number (412 taxa), followed by the Chlorophyta (180 taxa), Phaeophyceae (147 taxa) and Cyanobacteria (88 taxa). This species richness is comparable to that of the Philippines (1011 species) and considerably higher than that of Taiwan (288 species), Thailand (182 species) or Malaysia (241 species), which indicates that Vietnam possibly represents a diversity hotspot for macroalgae (Nguyen Van Tu et al.) [1].

In May 2013, a scientific expedition was organized by the Vietnam Academy of Science and Technology and the Russian Academy of Sciences in the frame of the VAST-FEBRAS
International collaboration program on the ship "ACADEMICIAN OPARIN". Samples of about 60 stations along the coast of Vietnam from Quang Ninh to Kien Giang at depths of $1 \mathrm{~m}$ to $10 \mathrm{~m}$ have been collected. Some of the stations were off islands like Tho Chu, Con Dao, Phu Quy, Cu Lao Xanh and Ly Son. The results demonstrated that the waters surrounding the islands are high biodiversity areas with their coral reefs and the associated flora and fauna. The team collected and identified a total of 118 taxa of marine algae, of which six taxa were newly recorded for Vietnam.

\section{MATERIALS AND METHODS}

The herbarium specimens used for this study were collected from some stations along the coast of Vietnam from Quang Ninh to Kien Giang during the $5^{\text {th }}$ Russian - Vietnamese 
marine scientific expedition aboard the research vessel "ACADEMICIAN OPARIN", by snorkeling and SCUBA diving around the islands and by scraping off substrata like rocks and dead corals between 1 and 10 meters in depth. All specimens were cleaned and pressed into herbarium vouchers, or preserved in 5\% formalin in seawater. The specimens were identified based on morphological and anatomical data, using published keys and taxonomic papers largely following Taylor $(1965,1975)$ [2, 3], De Clerck et al., (2005) [4], Huisman et al., (2007) [5], Belton et al., (2014) [6] and Draisma et al., (2014) [7]. All specimens were deposited in the Herbarium of the Nha Trang Institute of Technology Research and Application (NITRA). The cross sections were cut by hand and were stained in $1 \%$ acidified aniline-blue solution and mounted on glass slides in 20\% Karo syrup. Microscopic photographs were made by using an Olympus camera attached to a Nikon microscope and in situ photographs were made by Olympus Stylus Tough-8000 in the USA. All photographs were edited with Photoshop 7.0. The taxonomy and nomenclature of the species largely follows website www.algaebase.org (Guiry, M. D., and Guiry, G. M., 2014 [8]).

\section{RESULTS AND DISCUSSION Order Nemastomatales, Rhodophyta}

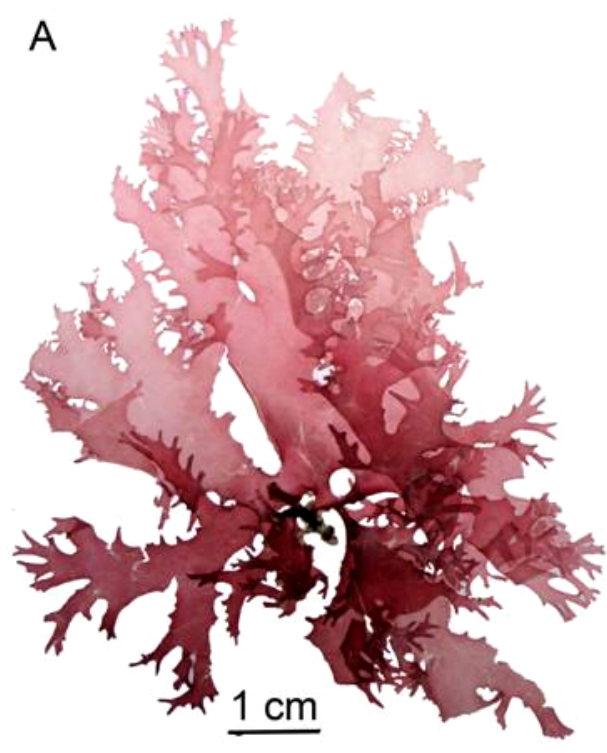

\section{Titanophora pikeana (Dickie) Feldmann,} 1942: 111 [9]

References: Schils T. and Coppejans E. (2002: 261, figs. 36-44, [10]). Huisman et al., (2007: 101, [5]).

Synonym: Galaxaura pikeana Dickie 1874; Halymenia pickeana (Dickie) J.Agardh 1885; Platoma pikeanum (Dickie) Weber-van Bosse 1921.

Description: Thallus attached by a basal disk, forming slick, soft flattened dissected blades, slightly calcified in the central tissues, up to $8-11.5 \mathrm{~cm}$ high, whitish pink to livercoloured and chalky rose-white when dried; branches marginally dissected, pinnate to irregular, younger branches somewhat dichotomous. Main axis flat, 7 - $10 \mathrm{~mm}$ wide, $0.5-1.2 \mathrm{~mm}$ thick. Branchlets flattened, apices forked, tapering, bluntly pointed. Medulla of one to several loosely arranged longitudinal filaments (cells $10-15 \mu \mathrm{m}$ diam., 100 $150 \mu \mathrm{m}$ long) and many loosely intertwined secondary filaments (cells 5 - $7 \mu \mathrm{m}$ diam., 20 $30 \mu \mathrm{m}$ long) within a mucilaginous gel. Cortex $20-30 \mu \mathrm{m}$ thick, cells spherical to oval, 5 $7 \mu \mathrm{m}$ diam., 7 - $10 \mu \mathrm{m}$ long (fig. 1). Medulla filaments 2 - 3 times di-trichotomously branched, 7 - $10 \mu \mathrm{m}$ diam., 45 - $60 \mu \mathrm{m}$ long;

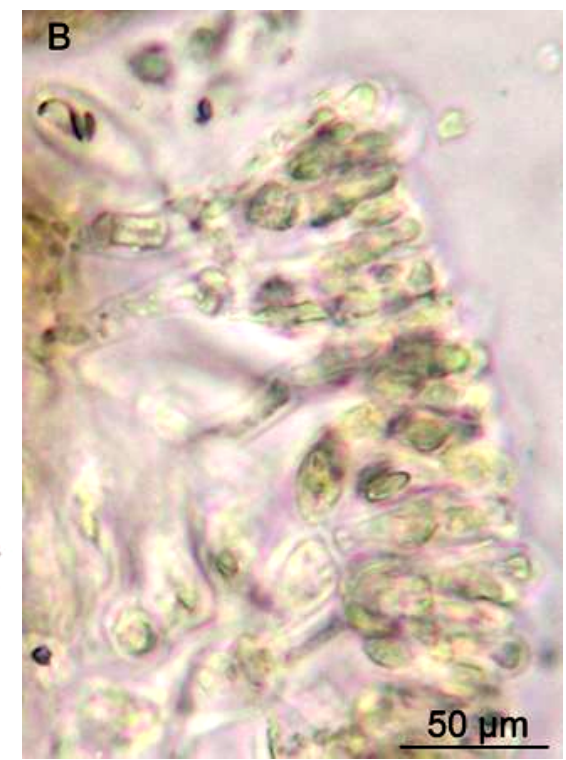

Fig. 1. Titanophora pikeana (Dickie) Feldmann (A) Habit; (B) Cross section of cortex 
Type locality: Mauritius.

Ecology: Growing on dead coral at $10 \mathrm{~m}$ depth.

Geographical distribution: South Africa, Madagascar, Mauritius, Réunion, Tanzania, , Sri Lanka, Vietnam, Indonesia, Philippines, Papua New Guinea, Western Australia, Fiji, Hawaii.

Voucher: NITRA 2101, 2102 and 2103, 28 May 2013, $10 \mathrm{~m}$ depth at $\mathrm{Cu} \mathrm{Lao}$ Xanh Island (13 36'11.09'N, 109 21'48.84'E), Binh Dinh, Vietnam.

Remark: The separation into species within the genus Titanophora is a heavily debated problem. Mshigeni \& Papenfuss (1980) [11] listed eight species worldwide, separated on the basis of their reproductive and vegetative characters. However, for many characters no information is available, resulting in Norris (1992) [12] stating: "It seems likely that there is a single variable species in this genus". It is, however suggested (Masuda \& Guiry 1995, p. 66, footnote [13]) that no decisions can be made until pre- and post-fertilization events of all described entities have been studied. The entity Titanophora pulchra E. Y. Dawson [14] from Nha Trang, Vietnam has been synonymized to Titanophora pikeana [1], but by other researchers to Titanophora weberae (N'Yeurt 2001 [15]) Morphologically, Titanophora pulchra E. Y. Dawson, (see Tsutsui et al., 2005 [16]) and T. weberae Børgesen (De Clerck et al., 2005 [4]) can both be separated from $T$. pikeana by the light degree of calcium carbonate crystals to the medullary layer and the mucronate, freely projecting papilliform cells and small proliferations along the margins of the thallus. It is, however, possible that calcification with aragonite is not the unifying character it is claimed to be (Masuda \& Guiry, 1994 [17]). T. incrustans (J. Agardh) Børgesen can be separated from these three taxa because it lacks a cylindrical stalk (Littler \& Littler, 2000 [18]).

\section{Order Ceramiales, Rhodophyta}

Laurencia natalensis Kylin 1938: 24, pl. 8, fig. 21 [19].

References: Coppejans et al. (2009: 218, figs. 11D, 22I, 186E) [20]; De Clerck et al. (2005 : 256, fig. 263) [4].

Synonym: Laurencia obtusa var. natalensis (Kylin) Børgesen 1945

Description: Thallus creeping or sprawling, tough, cartilaginous, up to $2 \mathrm{~cm}$ high, to $6 \mathrm{~cm}$ in diameter, branching irregular, growing in extensive vegetations with the basal parts being greenish and the apices orangey-red; and black when dried. Branches cylindrical, $0.8-1.0 \mathrm{~mm}$ in diam. Branchlets generally arranged in spirals, occasionally opposite, $0.3-0.5 \mathrm{~mm}$ in diam. 0.2 - $1.5(-3.0) \mathrm{mm}$ long, blunt, wart-like, often swollen; apices tufted with fine deciduous, dichotomously branched filaments, sunken in terminal depression. Surface cells oval, 25 $30 \mu \mathrm{m}$ in diam.; medullary cells $80-100 \mu \mathrm{m}$ in diam., colorless, apical cell sunken in a terminal depression. Holdfast inconspicuous, pad-like; secondarily attached by numerous lateral rhizoids arising from branches. Tetrasporangial branchlets slightly enlarged; tetrasporangia tetrahedrally divided, in a single whorl near the branch apex (fig. 2).
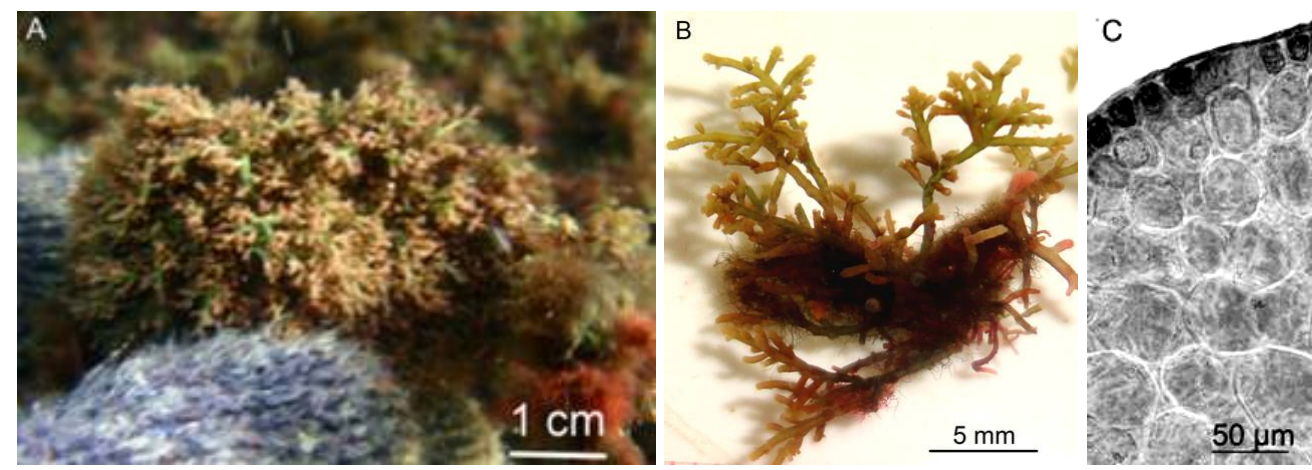

Fig. 2. Laurencia natalensis Kylin. (A) In situ habit; (B) Habit;

(C) Cross section showing tetrasporangia 
Type locality: Isipingo Beach, near Durban, South Africa.

Ecology: On hard substrates to wave exposure, intertidal to $1 \mathrm{~m}$ depth.

Distribution: Kenya, Mozambique, South Africa, Sri Lanka.

Voucher: NITRA 2111-2118, 16 May 2013, $1 \mathrm{~m}$ depth at Tho Chu Island $\left(9^{0} 19^{\prime} 12.14{ }^{\prime} \mathrm{N}\right.$, $103^{0} 29$ '53.77'’E), Kien Giang, Vietnam.

Remark: This is the most abundant Laurencia species just above low tide level. This species is distinguished from the other Laurencia species by its growing in extensive vegetations with the basal parts being greenish and the apices orangey-red (De Clerck et al., (2005) [4]).

\section{Order Rhodymeniales, Rhodophyta}

\section{Coelothrix irregularis (Harvey) Børgesen} 1920: 389, figs 373, 374 [21]

References: Taylor (1960: 488, Pl. 45, fig. 3; pl. 46, fig. 4)[22]; Yoshida (1998: 847, figs.
B-E)[23]; Littler \& Littler (2000: 137, figs. 13) $[18]$.

Synonym: Harvey 1853.

Type locality: Key West, Florida, USA.

Description: Thallus tuft-like, wiry, entangled, up to $3 \mathrm{~cm}$ high, branching irregular; bright iridescent blue and purple-red when dried. Branches cylindrical, $0.3-0.8 \mathrm{~mm}$ in diam., rigid; apices tapering, bluntly pointed. Central cavity filled with clear mucilaginous gel, $100-120 \mu \mathrm{m}$ in diam.; lined with scarce longitudinal filaments with spherical to clubshaped gland cells, projecting into cavity. Cortex 4 - 6 cells with thick walls; inner cells (near cavity), elongated, $15-27 \mu \mathrm{m}$ in diam., 30 - $50 \mu \mathrm{m}$ long; surface cells spherical, 15 $17 \mu \mathrm{m}$ diam., heavily pigmented. Tetrasporangia irregularly spherical, 20 $30 \mu \mathrm{m}$ in diam. Spermatangial sori swollen at branch apices. Cystocarps spherical, 300 $400 \mu \mathrm{m}$ diam., solitary or in clusters of $3-4$ (fig. 3).
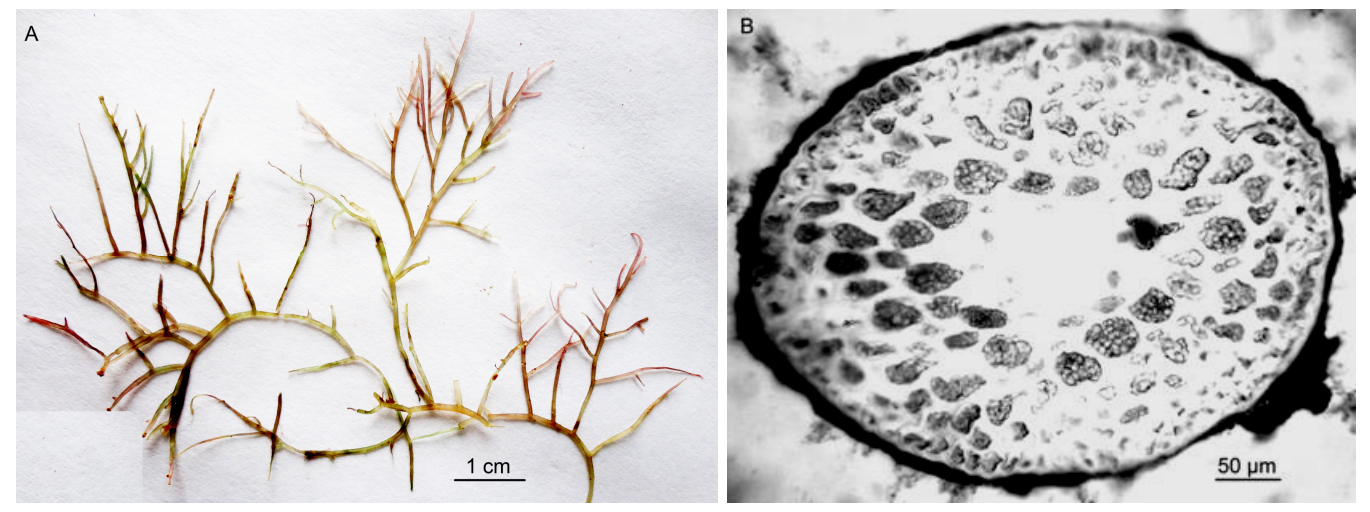

Fig. 3. Coelothrix irregularis (Harvey) Børgesen. (A) Habit of thallus ; (B) Cross section of a branch with tetrasporangia and showed a cavity at the central medulla

Distribution: Portugal, Bermuda, Canary Islands, Florida, Belize, Bahamas, Caribbean, Brazil, China, Japan, Philippines, Australia and New Zealand, Hawaiian Islands.

Voucher: NITRA 2131, 17 May 2013, 2 m depth at Con Dao Island (8 39'14.05'N, $\left.106^{0} 33^{\prime} 34.08^{\prime \prime E}\right)$, Kien Giang, Vietnam.

Remark: This species can be distinguished from Pterocladia spp., Gelidiopsis variabilis and Gelidiella spp. by having a central cavity lined with scarce longitudinal filaments beset with gland cells [24].

\section{Order Bryopsidales, Chlorophyta}

\section{Caulerpa falcifolia Harvey \& Bailey 1851: 373 [25]}

Synonym: $C$. taxifolia var. falcifolia [Harvey \& Bailey] W. R. Taylor; C. taxifolia f. tristichophylla Svedelius 
Stolons sparsely branched, $1.0-1.5 \mathrm{~mm}$ in diam. forming mats on rocks and sand, in the supralittoral zone. Erect branches (assimilators) up to $4-8 \mathrm{~cm}$ high, $1.2-1.5 \mathrm{~mm}$ in diam., naked for about $5 \mathrm{~mm}$ at the base; simple or occasionally subdichotomous. Branchlets radially arranged into $6-8$ rows along the main erect branches, flattened, 3.5 - $4 \mathrm{~mm}$ long, 0.7 $0.9 \mathrm{~mm}$ in diam., $0.2-0.25 \mathrm{~mm}$ thick, but narrower on the more crowed axes, closely placed, up-curved, gradually tapering to the acuminate apex, constricted at the base, not overlapping (fig. 4). Thallus has light green in color but pale yellow-green when dried.
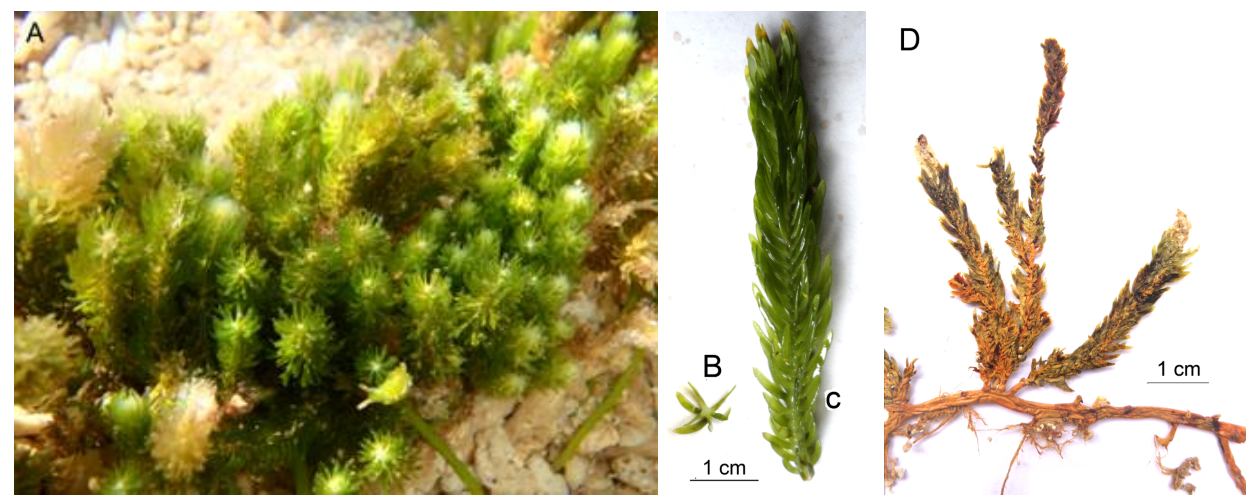

Fig. 4. Caulerpa falcifolia Harvey \& J. W. Bailey. (A) In situ habit of; (B) a cross section of an assimilator showed branchlets radially arranged into 6 rows along the main erect branches;

(C) an assimilator; and (D) a branching system from herbarium specimen NITRA 2141

Type locality: Tongatapu, Friendly Islands.

Distribution: Indonesia, Qld., Tonga, Central Polynesia, North-West Australia, Queensland.

Vouchers: NITRA 2141-2146, 29 May 2013, 2 m depth, Ly Son Island $\left(15^{0} 22^{\prime}\right.$ 44.5206”N, 109 08'59.8290”E), Quang Ngai, Vietnam.

Remark: These specimens have the form of Caulerpa taxifolia judged from the presence of basal constrictions and elongated branchlets, suggesting relation with infraspecific taxa of $C$. taxifolia like Caulerpa taxifolia var. tristichophylla with three rows of ramuli at the base of the assimilators (Svedelius 1906 [26]), Caulerpa taxifolia f. falcifolia (Harvey \& Bailey) W. R. Taylor with 3 or more rows in the whole of the assimilators [3]. They do not belong to $C$. mexicana var. pluriseriata W.R. Taylor [3] because our plants have shorter branchlets and have only slight or even no constrictions at the base of the branchlets being arranged in more rows and with the presence of long rhizoidal pillars, which are absent in $C$. mexicana (Taylor, W. R., 1975 [3]). It also does not fit the description of Caulerpa reyesii Meñez \& Calumpong [27], because that species has overlapping, obovate, clavate branchlets, which can, however, be arranged distichously or tetrastichously [27]. According to comparison with the characters described above, we conclude to have found Caulerpa taxifolia var. falcifolia (Harv. \& J. W. Bailey) W. R. Taylor. However, in a recent paper of Draisma et al, (2014) [7], this taxon was proposed here to reject Caulerpa taxifolia var. falcifolia (Harv. $\&$ J. W. Bailey) W. R. Taylor and to reinstate $C$. falcifolia Harvey \& Bailey.

\section{[28]}

Caulerpa oligophylla Montagne 1842: 14

References: Belton et al. 2014: 46, figs 1B, 5A-F [6]; Weber-van Bosse 1898: 368-370, pl. XXXII, fig. 1-6.[29]; Coppejans and Beeckman (1989: 388-391, plate 2, fig. 7-9, plate 2, fig. 11-20 [30]; Taylor (1960: 153) [22]; Littler and Littler (2000:370-371) [18].

Often identified as Caulerpa racemosa var. lamourouxii (Turner) Weber-van Bosse 1898: 369, pl. XXXII, figs. 1-4 [29], or as Caulerpa lamourouxii (Turner) C. Agardh 1817: XXII [31]. 
Stolons cylindrical growing on dead coral; erect branches $2-6 \mathrm{~cm}$ high, cylindrical at the base, 3 - 5 (-10) mm long, 1 - $1.2 \mathrm{~mm}$ wide, then slightly compressed and constricted or of irregular width, $2 \mathrm{~cm}$ to $4 \mathrm{~cm}$ high, $3-5 \mathrm{~mm}$ wide, with (sub-)opposite (sub-)spherical branchlets or sometimes partly naked or bearing a single to more spherical branchlets. Branchlets (sub-) spherical, 2 - $3 \mathrm{~mm}$ diam., branchlet stalks $1-1.2 \mathrm{~mm}$ long (fig. 5). Thallus have grass - green in color but dark green when dried.
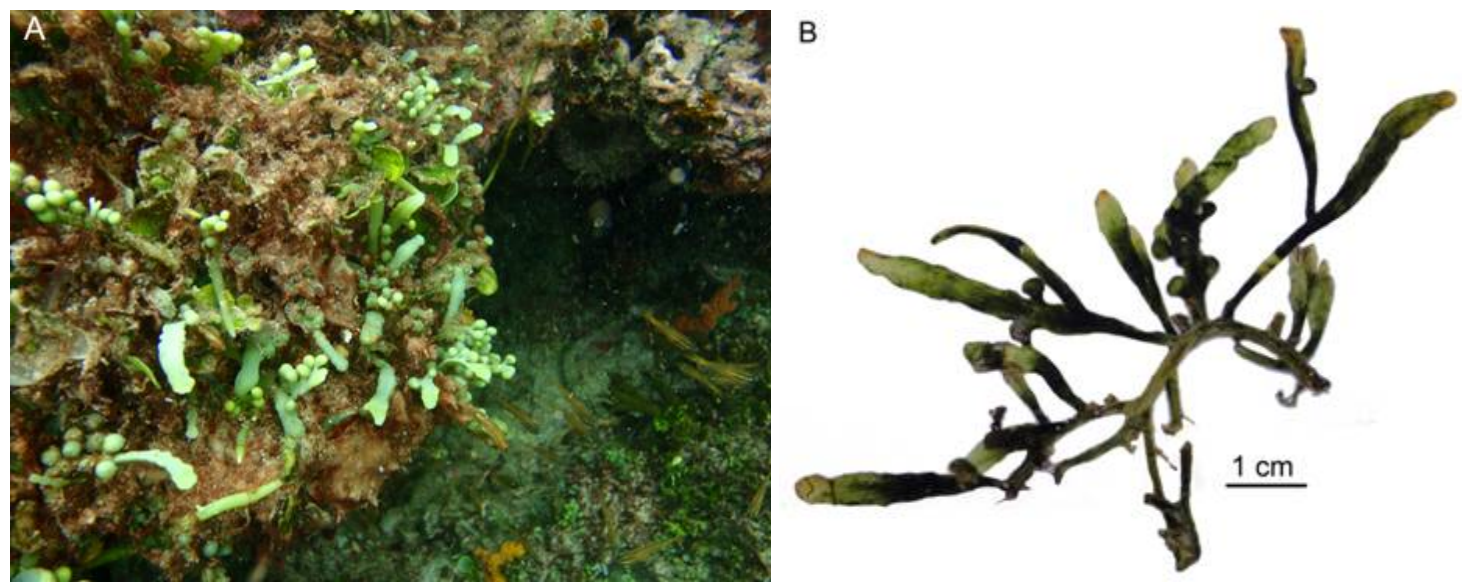

Fig. 5. Caulerpa oligophylla Montagne (A) In situ habit; (B) Flattened assimilators with some spherical branchlets at their base in the herbarium specimen NITRA 2151

Type locality: Western Australia.

Ecology: On hard substrates to wave exposure, intertidal to $2.5 \mathrm{~m}$ depth.

Distribution: Japan, Indonesia, Philippines, Queensland, Caledonia.

Vouchers: NITRA 2151 - 2154, 2158 2160, 29 May 2013, $2.5 \mathrm{~m}$ depth, Phu Quy Island (10031'19.57'N, 108 $57^{\circ} 35.59$ 'E), Binh Thuan, Vietnam.

Remarks: This species is somewhat similar to $C$. racemosa but its erect branches are very variable and occasionally partly naked, then slightly compressed and constricted or of irregular width, on its spherical branchlets which are either extremely rare, occasionally completely lacking (= forme requienii) and irregularly placed or more frequent and then often (sub-)opposite.

Remark: In a paper by Belton et al., [6] a new classification has been proposed for the taxa within the Caulerpa racemosa-peltata complex and it was demonstrated that the entities within Caulerpa racemosa var. lamourouxii represent two Caulerpa species viz. C. oligophylla Montagne and $C$. lamourouxii (Turner) C. Agardh. Although these taxa are clearly different when studied by molecular methods (sequencing studies), the two species cannot be differentiated by morphological studies. The study by Belton et al., [6] showed different areas of occurrence for C. lamourouxii (Indian Ocean and Red Sea) and C. oligophylla (Northeastern Australia, New Caledonia, Indonesia, the Philippines and Japan). The latter species is most possibly widespread throughout the western Pacific Ocean and can be supposed to be the species that occurs in Vietnam. The specimens identified as $C$. lamourouxii recorded in Coppejans \& Beeckman 1989 [30] do most probably really belong to that species, while those published as $C$. racemosa var. lamourouxii in Littler \& Littler 2003, p. 228229 [32] and in Verheij \& Prud'homme van Reine 1993, p. 396 [33] most probably belong to C. oligophylla. According to Belton et al., (2014, p. 46, [6]) the supposed C. racemosa var. lamourouxii in Taylor (1960: p. 153, [22]) and in Littler \& Littler (2003, p. 370, 371 [32]) do not belong to that taxon but to the Caulerpa 
chemnitzia clade; C. lamourouxii does, most likely, not occur in the tropical western Atlantic Ocean.

Caulerpa racemosa var. lamourouxii and $C$. oligophylla are morphologically closely resembling Caulerpa racemosa with few or more (sub-)opposite (sub-)spherical branchlets along the assimilators.

Caulerpa andamanensis (W. R. Taylor) Draisma, Prudhomme et Sauvage 2014: 1020 [8]

References: Coppejans et al. (2009: 104, figs. $27 \mathrm{G}, 80)$ [20].
Basionym: Caulerpa filicoides var. andamanensis W. R. Taylor 1965: 154-156, fig. 1 [2]

Thallus forming dense, soft and slender, green tufts. Stolons thin, up to $0.2 \mathrm{~mm}$ in diam., sparsely branched, well fixed by very numerous groups of rhizoids. Assimilators with a thin, vertically placed stipe $1-1,5 \mathrm{~mm}$ long, mostly simple, more rarely branched, terminally bearing usually a single, horizontally placed whorl of 6 - 8 branchlets. Each branchlet is branching dichotomously at the base, alternately branched higher up, with acute apices and with the general outlook of a snow crystal (fig. 6). Thallus has green to yellowgreen in color but dark green when dried.
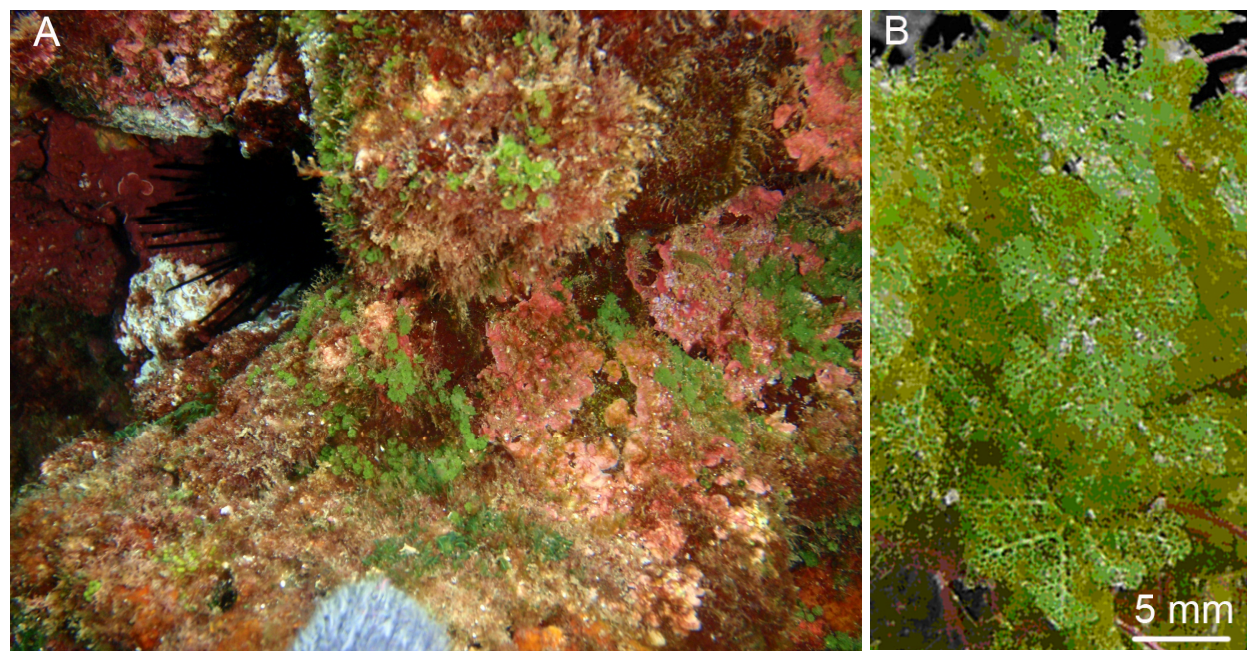

Figure 6. Caulerpa andamanensis (W. R. Taylor) Draisma, Prud'homme \& Sauvage (A) In situ habit; (B) In situ close-up of the whorls of $6-8$ branchlets on the top of the upper parts of the stipes

Type locality: Northeast of Ritchie's but the branchlets are arranged in a single Archipelago, Andaman Islands.

Ecology: On rocks and other hard surfaces, sublittoral to $3 \mathrm{~m}$ depth.

Distribution: Tanzania, India, Sri Lanka, Andaman Islands, Palau, Micronesia, Papua New Guinea, Australia, Fiji, and also Hawaii.

Voucher: NITRA 2155, 2156, 29 May 2013, 3 m depth, Phu Quy Island (10 31 '15.45”N, $108^{0} 57^{\prime} 40.92$ 'E), Binh Thuan, Vietnam.

Remark: The appearance of this species in the field is in size very similar to C. verticillata horizontally placed whorl on the top of the upper parts of the stipes. In previous paper, Taylor (1965) [2] has identified it as Caulerpa filicoides var. andamanensis but in recent paper of Draisma et al., (2014) [7] this taxon was considered to form a separate species, viz. Caulerpa andamanensis (W. R. Taylor) Draisma, Prud'homme \& Sauvage.

Acknowledgements: This study was financially supported by the VAST-FEBRAS International collaboration between the Vietnam Academy of Science and Technology 
(VAST) and the Russian Academy of Sciences (RAS), with the code of VAST.HTQT. Nga 06. 13-14. The authors wish to express their thanks to Dr. Dimitrii Pelageev, Victor and Boris for assistance during the survey. Thanks also to Willem Prud'homme van Reine (Naturalis Biodiversity Center, Leiden, The Netherlands) and Stefano Draisma (Institute of Ocean and Earth Sciences, University of Malaya, Kuala Lumpur, Malaysia) for assistance in the comparison of some of specimens and reviewing an earlier draft of the manuscript.

\section{REFERENCES}

1. Nguyen Van Tu, Le Nhu Hau, Lin S-M., Steen F. and De Clerck O., 2013. Checklist of the marine macroalgae of Vietnam. Botanica Marina, 56(3): 207-227.

2. Taylor, W., 1965. An interesting Caulerpa from the Andaman Sea. Journal of Phycology, 1(4), 154-156.

3. Taylor, W. R., 1975. A noteworthy variant Caulerpa. University Herbarium, University of Michigan. Pp. 77-79.

4. De Clerck, O., Tronchin, E. M., Schils, T., 2005. Red algae. Rhodophyceae. Guide to the seaweeds of KwaZulu-Natal. Scripta Botanica Belgica 33, 131-267

5. Huisman, J. M., Abbott, I. A., and Smith, C. M., 2007. Hawaiian reef plants. University of Hawaii Sea Grant College.

6. Belton, G. S., Reine, W. F., Huisman, J. M., Draisma, S. G., Gurgel, D., and Frederico, C., 2014. Resolving phenotypic plasticity and species designation in the morphologically challenging Caulerpa racemosa-peltata complex (Chlorophyta, Caulerpaceae). Journal of Phycology, 50(1): 32-54.

7. Draisma, S. G., Reine, W. F., Sauvage, T., Belton, G. S., Gurgel, C. F. D., Lim, P. E., and Phang, S. M., 2014. A re-assessment of the infra-generic classification of the genus Caulerpa (Caulerpaceae, Chlorophyta) inferred from a time-calibrated molecular phylogeny. Journal of Phycology, 50(6): 1020-1034.
8. Guiry, M. D., and Guiry, G. M., 2014. AlgaeBase. World-wide electronic publication, National University of Ireland, Galway, http://www.algaebase.org, searched June 2014.

9. Feldmann, J., 1942. Remarques sur les Némastomacées. Bulletin de la Société botanique de France, 89(4-6): 104-113.

10. Schils, T., and Coppejans, E., 2002. Gelatinous red algae of the Arabian Sea, including Platoma heteromorphum sp. nov. (Gigartinales, Rhodophyta). Phycologia, 41(3): 254-267.

11. Mshigeni, K. E., and Papenfuss, G. F., 1980. New records of the occurrence of the red algal genus Titanophora (Gigartinales: Gymnophlaeaceae) in the western Indian Ocean, with observations on the anatomy of the species found. Botanica Marina.

12. Norris, R. E., 1992. Six marine macroalgal genera new to South Africa. South African journal of botany: official journal of the South African Association of Botanists= Suid-Afrikaanse tydskrif vir plantkunde: amptelike tydskrif van die Suid-Afrikaanse Genootskap van Plantkundiges.

13. Masuda, M., and Guiry, M. D., 1995. Reproductive morphology of Itonoa marginifera (J. Agardh) gen. et comb. nov. (Nemastomataceae, Rhodophyta). European Journal of Phycology, 30(1): 57-67.

14. Dawson, E. Y., 1954. Marine plants in the vicinity of the Institut Océanographique de Nha Trang, Vietnam. Pacific Science, 8, 372-469.

15. Antoine De Ramon, N. Y., 2001. Marine algae from the Suva Lagoon and reef, Fiji. Australian Systematic Botany, 14(5): 689-869.

16. Tsutsui, I., Huybh, Q. N., Nguyen, H. D., Arai, S., and Yoshida, T., 2005. The common marine plants of southern Vietnam. Numerous colour photographs USA: Japan Seaweed Association, 251, 1-250.

17. Masuda, M., and Guiry, M. D., 1994. The reproductive morphology of Platoma cyclocolpum (Nemastomataceae, 
Gigartinales) from Gran Canaria, Canary Islands. Cryptogamie. Algologie, 15(3): 191-212.

18. Littler, D. S., and Littler, M. M., 2000. Caribbean reef plants. An Identification Guide to the Reef Plants of the Caribbean, Bahamas, Florida and Gulf of Mexico. Washington: Offshore Graphics. Inc. 542 p.

19. Kylin, H., 1938. Verzeichnis einiger Rhodophyceen von Südafrika. Lunds Universitets årsskrift. N.F. avd., 34(8): 126.

20. Coppejans, E., Leliaert, F., Dargent, O., Gunasekara, R., and De Clerck, O., 2009. Sri Lankan seaweeds: Methodologies and field guide to the dominant species. Abc Taxa, 6: i-viii, 1-265.

21. Børgesen, F., 1920. The marine algae of the Danish West Indies, Part 3: Rhodophyceae (6). Dansk Botanisk Arkiv 3: 1-504.

22. Taylor, W. R., 1960. Marine algae of the eastern tropical and subtropical coasts of the Americas.

23. Yoshida, T., 1998. Marine algae of Japan. Uchida Rokakuho Publishing.

24. Le Gall, L., Dalen, J. L., and Saunders, G. $W ., 2008$. Phylogenetic analyses of the red algal order rhodymeniales supports recognition of the hymenocladiaceae fam. Nov., fryeellaceae fam. Nov., and neogastroclonium gen. Nov. 1. Journal of phycology, 44(6): 1556-1571.

25. Harvey, W. H., and Bailey, J. W., 1851. [Dr. Gould presented, in behalf of Professors W.H. Harvey of Trinity College, Dublin, and J.W. Bailey of West Point, descriptions of seventeen new species of Algae collected by the United States Exploring
Expedition...]. Proceedings of the Boston Society of Natural History 3: 370-373.

26. Svedelius, N., 1906. Ecological and systematic studies of the Ceylon species of Caulerpa. Ceylon Marine Biological Reports 4: 81-144.

27. Meñez, E. G., and Calumpong, H. P., 1982. The genus Caulerpa from Central Visayas, Philippines. Smithsonian Institution Press, 17, 1-21.

28. Montagne, J. F. C., \& Jules-SébastienCésar Dumont d'Urville., 1842. Prodromus generum specierumque phycearum novarum: in itinere ad Polum Antarcticum Regis Ludovici Philippi jussu ab illustri Dumont D'Urville peracto collectarum: notis diagnosticis tantum huc evulgatarum, descriptionibus vero fusioribus nec non iconibus analyticis jam jamque illustrandarum. Apud Gide.

29. Weber-van Bosse, A., 1898. Monographie des Caulerpes.. Annales du Jardin Botanique de Buitenzorg 15: 243-401, plates XX-XXXIV.

30. Coppejans, E., and Beeckman, T., 1989. Caulerpa section Sedoideae (Chlorophyta, Caulerpales) from the Kenyan coast. Nova Hedwigia, 49(3-4): 381-393.

31. Algarum Scandinaviae, S., 1817. Adjecla disposilione universali algarum. $\mathrm{xl}+135 \mathrm{p}$.

32. Littler, D. S., and Littler, M. M., 2003. South Pacific reef plants. A diver's guide to the plant life of the South Pacific coral reefs. Off Shore Graphics. Inc., Washington, DC.

33. Verheij, E., 1993. Seaweeds of the Spermonde Archipelago, SW Sulawesi, Indonesia. Blumea, 37, 385-510. 


\title{
MỘT SỐ LOÀI RONG BIỂN BỔ SUNG MỚI CHO KHU HỆ RONG BIỂN VIỆT NAM
}

\author{
Lê Như Hậu, Bùi Minh Lý, Trần Văn Huynh, Võ Thành Trung
}

Viện Nghiên cứu và Úng dụng Công nghệ Nha Trang-

Viện Hàn lâm Khoa học và Công nghệ Việt Nam

TÓM TÄT: Tháng 5 năm 2013, trong khuôn khổ Chuơng trình hợp tác giữa Viện Hàn lâm Khoa học và Công nghệ Việt Nam (VAST) với Phân Viện Biển Đông Viện Hàn lâm Khoa học Nga (FEBRAS), đã tổ chức một chuyến khảo sát chung Việt Nam - Liên bang Nga lần thư 5 trên tàu nghiên cưu "Viện Sĩ Oparin" trong vùng biển Việt Nam. Mục đích thu thập mẫu vật cho nghiên cưu đa dạng sinh vật và hóa sinh của vùng nước ven bờ Việt Nam. Sáu loài rong biển được ghi nhận mới cho khu hệ rong biển Việt Nam. Chúng gồm nhũng loài rong đỏ là Titanophora pikeana (Dickie) Feldmann ở Cù Lao Xanh, Laurencia natalensis Kylin ở đảo Thổ Chu và Coelothrix irregularis (Harvey) Børgesen ở Côn Đảo, và nhũng loài rong lục là Caulerpa oligophylla Montagne, Caulerpa andamanensis (W.R. Taylor) Draisma, Prudhomme et Sauvage ở đảo Phú Quý và Caulerpa falcifolia Harvey \& Bailey ở đảo Lý Son. Do đó, số luợng loài và biến loài rong biển Việt Nam bây giờ là 833, gồm ngành rong Đỏ (415 loài và biến loài), ngành rong Nâu (147 loài và biến loài), ngành rong Luc (183 loài và biến loài) và ngành rong Lam (88 loài và biến loài).

Tù khóa: Caulerpa, Coelothrix, Laurencia, loài mói bổ sung, rong biển, Titanophora, Tàu "Viện sĩ Oparin". 